\title{
Alcohol Drinking, Apolipoprotein Polymorphisms and the Risk of Cardio- vascular Diseases
}

\author{
Flavio M. Ceci ${ }^{1}$, Mauro Ceccanti ${ }^{2}$, Carla Petrella ${ }^{3}$, Mario Vitali ${ }^{4}$, Marisa P. Messina ${ }^{5}$, George N. \\ Chaldakov $^{6}$, Antonio Greco ${ }^{7}$, Massimo Ralli ${ }^{7}$, Marco Lucarelli ${ }^{1}$, Antonio Angeloni ${ }^{1}$, Marco Fiore ${ }^{3, *}$ \\ and Giampiero Ferraguti ${ }^{1}$
}

${ }^{I}$ Department of Experimental Medicine, Sapienza University of Rome, Rome, Italy; ${ }^{2}$ Sitac, Societa' Italiana per lo Studio delle Patologie Alcool Derivate, Rome, Italy; ${ }^{3}$ Section of Neurobiology, Institute of Biochemistry and Cell Biology (IBBC-CNR), Rome, Italy; ${ }^{4}$ ASUR Marche, AV4, Ancona, Italy; ${ }^{5}$ Department of Gynecology, Obstetric, and Urology, Sapienza University of Rome, Rome, Italy; ${ }^{6}$ Department of Anatomy and Cell Biology, Medical University, and Institute for Advanced Study, Varna, Bulgaria; ' Department of Sense Organs, Medical Faculty, Sapienza University of Rome, Rome, Italy

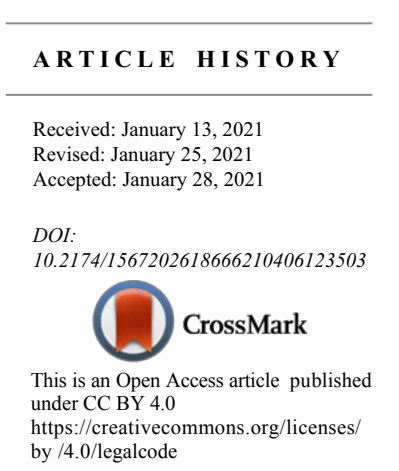

\begin{abstract}
Lipoprotein disorders are a major risk factor for atherosclerotic neuro-cardiovascular disease (ACVD) and are heavily influenced by lifestyle, including alcohol drinking. Moderate drinkers have a lower ACVD risk than abstainers due to their higher levels of high-density lipoprotein (HDL) cholesterol, an important protective factor against ACVD. On the contrary, heavy drinking increases ACVD risk. According to an extensive literature body, ethanol intoxication modifies lipid serum profile and induces endothelial dysfunction. Single nucleotide polymorphisms may influence the relationship between alcohol drinking, HDL cholesterol level, and atherosclerotic risk. The risk of ACVD in heavy drinkers seems enhanced in patients with apolipoprotein E4 allele, interleukin-6-174 polymorphism, and cholesteryl ester transfer protein TaqIB polymorphism. Apolipoprotein E4 is a known risk factor for ACVD, while apolipoprotein E2 has mixed effects. Therefore, even if a "protective role" may be attributed to moderate drinking, this effect cannot be extended to everyone.
\end{abstract}

Keywords: Alcoholism, genetic polymorphism, atherosclerotic cardiovascular disease, apolipoprotein E, adiponectin.

\section{INTRODUCTION}

Lipoprotein's primary function is to transport cholesterol and triglycerides. Insoluble in water, from the liver and intestine to peripheral tissue, it return lipids and cholesterol to the liver for clearance and recycling [1]. Lipoproteins are complex particles composed of a central hydrophobic core of non-polar lipids (triglycerides and cholesterol esters), surrounded by a hydrophilic membrane and consisting of phospholipids, free cholesterol, and apolipoproteins (Apo) (Fig. 1) $[2]$.

The Apo amphipathic properties allow them to surround the lipids, creating a water-soluble particle. Lipoproteins are classified according to their increasing density in chylomicrons, very-low-density lipoprotein (VLDL), intermediatedensity lipoprotein (IDL), low-density lipoprotein (LDL), and high-density lipoprotein (HDL) [3, 4].

The main functions of Apo are stabilizing lipoprotein structure and solubilizing lipid fraction, acting as a ligand for lipoprotein receptors and serving as activators or inhibit-

*Address correspondence to this author at the Section of Neurobiology, Institute of Biochemistry and Cell Biology (IBBC-CNR), Rome, Italy; E-mail: marco.fiore@enr.it ors of enzymes involved in the metabolism of lipoproteins $[1,5,6]$. There are various classes of Apo and several subclasses. Apolipoprotein E (ApoE) is a component of chylomicrons, chylomicron remnants, VLDL, IDL, and a subgroup of HDL, which promotes the hepatic clearance of triglyceride-rich lipoproteins owing to the binding to the lowdensity lipoprotein receptor (LDLR) [7, 8]. ApoE was initially described as a lipid transport protein and major ligand for LDL receptors (mediated via clathrin-coated vesicles) [9]. There are three genetic variants of ApoE: ApoE2, ApoE3, and ApoE4 [10]. Patients who are homozygote for APO E2 gene display the worst affinity for LDLR and higher plasma cholesterol levels, leading to type III hyperlipidemia in humans [11]. Whereas, ApoE4 is associated with an increased risk of Alzheimer's disease and an increased risk of atherosclerosis [12]. Taken together, this may open new therapeutic and nutraceutical, including moderate alcohol drinking, approaches to reduce apoE4 pathology in both and atherosclerotic cardiovascular diseases (ACVD), neurovascular disorders, and Alzheimer's disease.

ACVD is a large group of atherosclerosis-related diseases, including coronary heart disease, myocardial infarction, infarction, an ischemic or hemorrhagic stroke of the brain or the spinal cord, and peripheral arterial disease (carotid and 
legs atherosclerosis) [13-17]. Lipoprotein disorders are one of the main risk factors for ACVD [18-20]. High levels of LDL and triglycerides and low levels of HDL are the most important players in the process of atherogenesis [21-24]. Furthermore, an incorrect diet and lifestyle may enhance the risk: high cholesterol and high glucose diets, as well as smoking and heavy alcohol drinking may contribute to increased ACVD risk [25-28]. Several case-control and cohort studies have described a J- or U-shaped relationship between alcohol intake and ACVD: abstainers and heavy drinkers show greater ACVD risk than moderate drinkers [29-34]. The limit between moderate and heavy drinking is not established. According to the indications of the National Institute of Alcohol Abuse and Alcoholism (NIAAA) and the British Society of Cardiology, we considered "at-risk" people drinking up to 4 drinks per day or 14 per week for men (in Italy 1 drink $=12 \mathrm{~g}$ of alcohol), more than 3 drinks per day or 7 drinks per week for women [35-38]. NIAAA defines heavy drinking as 5 or more standard drinks in a day for a man and 4 or more standard drinks for a woman. However, women should avoid alcohol consumption during gestation and breastfeeding [39-43]. Furthermore, it is difficult to define a drink since alcoholic beverages can significantly differ in their alcohol content even within the same type of drink (e.g. beer, wine, or distilled spirits) [37]. Drinking patterns may be a confounding factor as well [44-46]. Binge drinking increases cardiovascular risk, while many studies suggest that alcohol consumed in moderation is beneficial for the cardiovascular system [47-49]. Also, red wine presents protective effects due to its antioxidant effect and the combination of ethanol with better nutrition. Phenolic compounds as resveratrol in the red wine are thought to be responsible for the protective effects as shown in humans and animal models [50-64]. Considering all these observations, it is not surprising that several studies regarding alcohol consumption and ACVD did not report consistent results.

\section{POLYMORPHISMS AND LIPID METABOLISM IN ALCOHOL DRINKERS}

\subsection{Positive Effects}

The S447X polymorphism results in the premature truncation of lipoprotein lipase (LPL), a fundamental enzyme of lipid metabolism [65]. In Asia, the S447X allele of the LPL gene is frequent, and S447X carriers have a low level of triglycerides in the plasma and a high level of HDL cholesterol. In this population, the $\mathrm{S} 447 \mathrm{X}$ allele seems to be associated with a less atherogenic lipid profile [66]. In Korea, the effect of the S447X allele was higher in men and women who consumed moderate levels of alcohol [67].

\subsection{Negative Effects}

Patients with ApoE4, an isoform of the $A P O E$ gene in humans, display increased plasma LDL cholesterol levels and lower HDL cholesterol plasma levels. Therefore, ACVD risk seems to be enhanced [68-72]. As for the Interleukin-6 (IL-6) genotype, drinkers and smokers with CC IL-6-174 polymorphism or the CG IL-6-174 polymorphism have a higher risk of coronary artery diseases $[73,74]$.

\subsection{Mixed Effects}

Alcohol-dehydrogenase enzymes (ADH) encoded by the $A D H 1 A, A D H 1 B$, and $A D H 1 C$ genes are mainly responsible for oxidizing ethanol to acetaldehyde $[75,76]$. Moderate drinkers who are homozygote for the slow-oxidizing $A D$ $H 1 C 2$ allele have higher HDL levels and a lowered risk of myocardial infarction. However, conflicting results are reported by others [77-79].

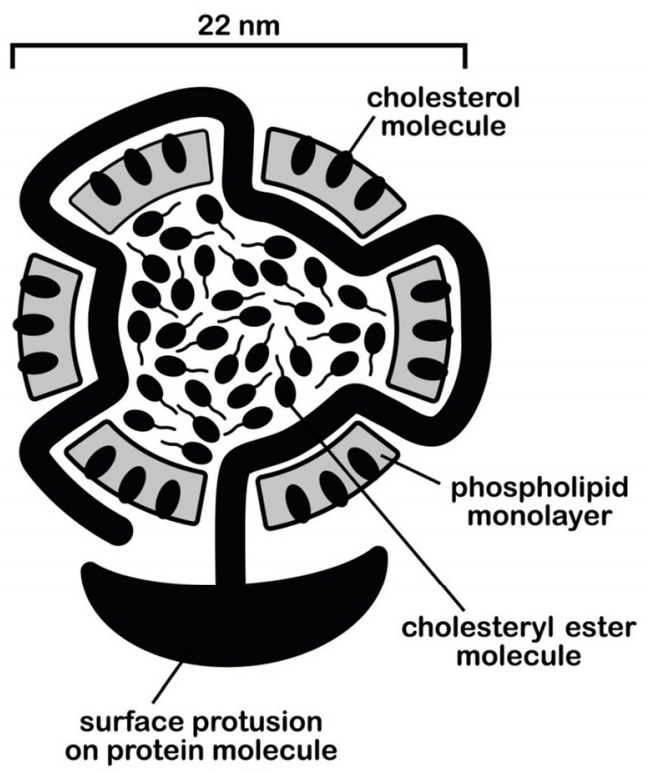

Fig. (1). Scheme of one molecule LDL, a particle with a diameter of $22 \mathrm{~nm}$ surrounded by a single lipid layer composed of around 800 phospholipids and 500 unesterified cholesterol molecules accompanied by one apolipoprotein B100 (ApoB-100) molecule and by minor apolipoproteins like apolipoprotein $\mathrm{E}$ (ApoE). In the core of the LDL particle are stored 1500 molecules of esterified cholesterol and about 170 triglycerides. LDL particles are a high-risk factor for developing cardiovascular disease. Modified from ref. [3].

ApoE is a circulating glycoprotein with a central role in lipid metabolism, promoting the clearance of residues of triglyceride-rich lipoproteins from the circulation into the liver [80]. Regarding ApoE polymorphisms, APOE \&2 heterozygotes are associated with increased ApoE levels, lower levels of cholesterol, lower LDL cholesterol levels, and higher triglycerides levels, when compared with APOE $\varepsilon 3$ homozygotes $[81,82]$. Whereas, ApoE4 heterozygotes are correlated with higher levels of cholesterol, LDL cholesterol, and triglycerides $[82,83]$. Of these two, the $\varepsilon 4$ isoforms are associated with higher coronary and carotid atherosclerosis risk and higher cardiovascular risk in diabetes mellitus [68, 84, $85]$.

Considering TaqIB polymorphism at cholesteryl ester transfer protein (CETP) locus, it has been shown that the B2 allele has increased HDL cholesterol level in moderate drinkers and higher levels in heavy drinkers with decreased atherogenic risk $[86,87]$. On the contrary, the B1B1 genotype seems to be a genetic risk factor for ACVD [88]. 


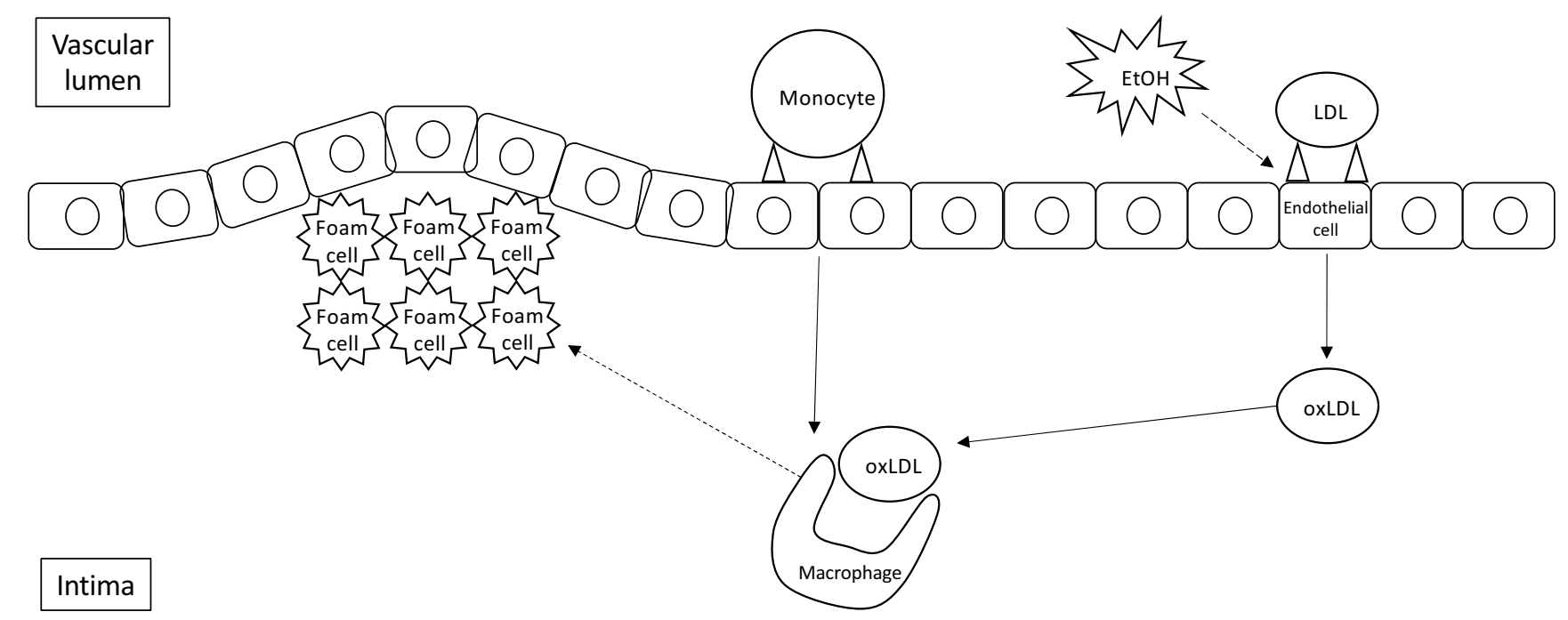

Fig. (2). Effects of alcohol abuse on atherosclerotic plaque formation. Excessive alcohol consumption is a risk factor for atherosclerotic disease. In particular, exposure of the endothelium to ethanol (EtOH) increases the production of reactive oxygen species that oxidize low-density lipoproteins (LDL) to oxidized LDL. The subsequent phagocytosis of ox-LDL by macrophages in the intima leads to the accumulation of foam cells, chronic inflammation of the intima, and the formation of atherosclerotic plaque. Over time, this hemodynamic alteration results in coronary artery disease, stroke, peripheral artery disease, kidney problems, heart attack, and aneurysm.

\section{ALCOHOL DRINKING AND ACVD RISK}

\subsection{Mechanisms}

Alcohol can be beneficial or harmful to the cardiovascular system, depending on the amount consumed, the characteristics of the consumer, and the quality of the alcohol. Most of the beneficial effect of moderate alcohol drinking against the atherosclerosis risk seems due to the increased HDL cholesterol, reduced triglycerides, total cholesterol, and LDL cholesterol [89-91]. Moderate alcohol consumption may enhance the cardioprotective function of HDL by upregulating the capacity of removing cholesterol, esterification of cholesterol, and the transfer of cholesteryl ester from HDL to the liver [92, 93]. Also, the elevation in HDL cholesterol levels may be due to increased hepatic production or increasing transport rate of apoA-I and apoA-II [91, 94, 95]. Lipoprotein lipase (LPL) is a fundamental enzyme responsible for the hydrolysis and transport of triglycerides [96]. Alcohol could also protect the cardiovascular system by increasing LPL activity which in turn decreases the triglycerides concentration in those subjects who consume a low quantity of alcohol [90].

Of note, the plasma level of adipokine adiponectin, a sanogenic protein produced by the adipocytes [25], increased in moderate drinkers [97, 98]. Adiponectin may exert anti-inflammatory and anti-atherogenic effects; it, therefore, plays a protective role against neuro-cardiovascular injuries $[99,100]$.

The relation between alcohol consumption and HDL cholesterol is mediated by the effect of alcohol on cholesteryl ester transfer protein (CETP) activity. The transfer of cholesteryl ester from HDLs to triglyceride-rich lipoproteins in exchange for triglycerides is driven by CETP: the increase in CETP activity reduces HDL cholesterol level and promotes atherosclerosis [101, 102]. On the contrary, alcohol drinking tends to deplete CETP activity, enhancing HDL cholesterol levels [103, 104].

While moderate drinking seems to have a protective role, heavy drinking is associated with endothelial and adipose dysfunction, increased atherosclerosis progression. Besides, a wide cluster of hemodynamic and vascular abnormalities indicate an unfavorable lipid profile and atherosclerotic risk even in former alcoholics who are disease-free [105-109]. Several studies show that heavy alcohol drinking alters lipid blood profile, causing hypertriglyceridemia, a risk factor for the development of atherosclerosis [110]. This alteration is due to increased levels of chylomicron and VLDL due to types of lipoproteins rich in triglycerides [111, $112]$.

Another mechanism by which alcohol abuse induces endothelial dysfunction and atherosclerosis is the alteration of oxidative stress and antioxidant defense [113]. Oxidative stress is defined as an imbalance between the oxidant and antioxidant system, causing an increase of reactive oxygen species (ROS) [114, 115]. Acetaldehyde, a product of alcohol metabolism, modifies the structure of the mitochondrial causing high production of ROS and lower synthesis of ATP [116]. Oxidative stress is a well-studied component of atherosclerosis pathogenesis, occurring in parallel with inflammation [114]. The excessive production of ROS is responsible for LDL oxidation [115]. Due to such modifications, LDL becomes atherogenic and accumulates in specific areas of the vascular wall. The subsequent internalization of LDL oxidized into macrophages gives rise to the foam cells, which is a hallmark of the early atherosclerotic lesion (Fig. 2) $[117,118]$. Recent findings showed that resveratrol and 
polyphenols extracted from the olives could counteract the oxidative stress induces by alcohol abuse throughout also a modulation of neurotrophins [50, 52-54].

\section{GENETIC POLYMORPHISMS, ALCOHOL DRINK- ING, AND ACVD RISK}

\subsection{APOE Polymorphisms}

ApoE lipoproteins rich in triglycerides are recycled in the liver from which HDL enriched in Apo E are secreted $[119,120]$. The main APOE alleles are E2, E3, and E4. These three alleles lead to different metabolic properties and different atherosclerosis risks [121, 122]. The distribution of these alleles is not the same between different populations, even though $\varepsilon 3$ is the most widespread, followed by $\varepsilon 2$ and $\varepsilon 4[123,124]$.

The allele $\varepsilon 4$ is the ancestral form in humans and presents two arginines at positions 112 and 158 of the ApoE amino acid sequence $[80,121,125]$. The affinity of these lipoproteins for the hepatic LDLR varies with the ApoE isoform $[68,126]$. The recycling of ApoE4 lipoproteins by the liver is reduced, and causes intracellular cholesterol accumulation, lower HDL-receptor expression and HDL cholesterol plasma level, reduced expression of LDLRs, and increasing plasma LDL cholesterol level $[68,69,126]$. All together, these alterations may increase atherosclerosis risk [70]. Furthermore, in ApoE4 non-obese postmenopausal women, alcohol drinking is associated with hypertension, which is a significant risk factor for the development of atherosclerosis $[127,128]$. Moreover, ApoE4 is the major genetic risk factor for Alzheimer's disease as this carrier is less efficient in transporting lipids from astrocytes to neurons than other isoforms $[129,130]$.

The $\varepsilon 2$ allele is the second most widespread allele and presents a cysteine and an arginine at positions 112 and 158 of the ApoE amino acid sequence [80,121, 125]. Subjects with this polymorphism have reduced affinity for LDLRs, leading to low LDL cholesterol and high HDL cholesterol levels, accumulating triglyceride-rich lipoprotein containing ApoE2 in plasma, and elevation of triglycerides level [131]. Moreover, a combination of $\varepsilon 2$ with the mutation $\varepsilon 1$ $\operatorname{Arg} 142$ Ser seems to be associated with severe type III hyperlipoproteinemia in patients with familial hypocholesterolemia [132]. Regarding Alzheimer's disease, ApoE2 protects the brain by accumulating less amyloid $\beta$ in the brain than other isoforms $[133,134]$.

Different studies report that alcohol may exert a positive action, but heavy drinking is responsible for atherosclerotic risk having a negative action on the release of nitric oxide by the endothelium $[135,136]$. This leads to vascular oxidative stress and reduces nitric oxide production, which are key events in the development of atherosclerosis $[137,138]$. The different ApoE isoforms can exert different antioxidant effects resulting in more or less atherogenic [139, 140]. In heavy drinkers, the oxidative stress and the HDL levels are increased: so the differences in atherogenic effect due to the various ApoE isoforms may be further enhanced [137, 141, $142]$.

\subsection{IL-6-174 Polymorphism}

Heavy alcohol drinkers with CC IL-6-174 polymorphism have higher levels of IL-6 and a higher risk of developing coronary artery diseases $[73,143]$. On the contrary, moderate alcohol drinking is correlated with lower levels of IL-6, lower levels of C-reactive protein, and reduced carotid intima-media thickness progression [144-146]. These results strongly suggest that inflammation is one of the mechanisms by which alcohol intoxication triggers the phenomenon of atherosclerosis, as also suggested by the close relationship between atherosclerosis and IL-6, the upstream inflammatory cytokine $[147,148]$.

\subsection{TaqIB Polymorphism and Cholesterylester Transfer Protein}

Transfer of cholesteryl ester from HDLs to triglyceride-rich lipoproteins in exchange for triglycerides is promoted by CETP: this transfer is increased in ACVD patients causing lower levels of HDL cholesterol [149, 150]. Instead, CETP deficiencies are associated with high HDL cholesterol serum levels and marked variations in the size and lipid composition $[151,152]$. TaqIB, a CETP polymorphism, is associated with high plasma HDL cholesterol levels, and the TaqIB B2B2 genotype shows the highest levels of HDL cholesterol $[153,154]$. The use of CETP inhibitors, alone or in combination with a statin, could be a valid option for patients with atherosclerotic disease as these drugs showed promising results in increasing HDL cholesterol levels [155, $156]$.

\subsection{Gender Effects}

The association between plasma lipids and alcohol intake depends on a context defined by gender, age, body mass index, and ApoE genotype [157-160]. As far as we know, the incidence of ACVDs in pre-menopausal women is virtually non-existent: so it is hypothesized a cardio-protective role of ovarian hormones achieved through a more favorable lipid profile $[161,162]$. In postmenopausal women, it appears that a beneficial effect of moderate alcohol consumption can be obtained on cardiovascular risk but with lower alcohol intake than men as women metabolize alcohol differently $[163,164]$. Alcohol catabolism is impaired in women due to smaller body size, larger body adipose tissue mass (alcohol is less soluble in body fat than in body water), and lower alcohol-dehydrogenase activity with decreased first-pass metabolism of alcohol in the stomach before arriving in the systemic circulation [165-168].

In a Chinese population, men with small artery occlusion who consume alcohol show the worst outcome, greater risk factors, and high LDL cholesterol plasma levels concerning women [169]. In APOE $\& 4$ carriers, plasma LDL cholesterol level, and ACVD risk were significantly higher in drinking than in non-drinking men, whereas in women, no differences were found [170]. Compared to women, men are more exposed to atherosclerotic risks [171]. The anti-atherogenic property of estrogens is mediated via at least two mechanisms: firstly by affecting plasma lipoprotein profiles promoting high levels of HDL and low levels of LDL; se- 
condary by downregulating the expression of adhesion molecules of the vessel wall after the exposure to atherogenic stimuli [172-174].

\subsection{Age Effects}

Among elderly postmenopausal women (over 65 years), ApoE4 carriers were found a negative effect of alcohol drinking concerning abstainers [175]. In non-obese postmenopausal women, alcohol consumption is associated with early systolic and diastolic hypertension in APOE genotype $\varepsilon 3 / 3$ compared to $\varepsilon 4$ carriers [122]. Furthermore, ApoE4 aged patients abusing alcohol display lower cognitive abilities [176, 177].

Similar results were obtained for ischemic stroke risk in elderly subjects: in the ApoE4 negative subjects, moderate drinking was associated with a lower risk than in abstainers, whereas in ApoE4 patients, the risk among moderate drinkers was higher than abstainers. In this study of older adults, the association of alcohol use and risk of ischemic stroke was U-shaped, with a modestly lower risk among consumers up to 6 drinks per week. However, ApoE genotype may modify this association, and even moderate alcohol intake may be associated with an increased risk of ischemic stroke among ApoE4-positive older adults [178].

Despite the substantial scientific evidence linking moderate alcohol use to lower risk of coronary heart diseases, the shape of the dose-response relationship between alcohol intake and coronary risk remains less consistent. No relationship was found between ApoE genotype and risk of myocardial infarction or coronary death in subjects over 65 years [179].

\section{CONCLUSION}

Many studies indicate that the ACVD risk in heavy drinkers is increased by genetic factors. An important goal is to provide genetic information for improving our ability to identify individuals with increased atherosclerosis risk, thus increasing our skill in the development of prevention programs.

ACVD risk in drinkers may be modulated by different polymorphisms well documented as ApoE, IL-6-174, S447X, TaqIB, and ADH1C. However, we focused on ApoE SNPs due to the relationship between alcohol drinking, ApoE single nucleotide polymorphism, and ACVD. In the primary prevention of alcoholism, people should be advised that heavy drinking may increase the atherosclerosis risk and that this risk may be further enhanced by specific genetic personal traits. At the present time, there is little awareness of these problems, and it could be quite useful to spread such information mainly among family doctors and other health and social professionals providing primary care.

The results relating to the risk of neuro-cardiovascular diseases in ApoE4 patients are worrisome since, in Caucasians, this isoform is present in approximately $13-25 \%$ of the general population. As a clinical strategy, the ApoE SNP should be routinely assessed, and the data should be considered for the treatment: in fact, the ACVD risk is enhanced for drinking ApoE4 people. This strategy would raise the cost of prevention since skillful operators and expensive equipment are needed. However, the relationship between cost/benefit may be favorable. As the prevalence of ApoE4 carriers is high in Caucasians and cardiac ischemic disease and ischemic stroke, that are the most worrisome ACVD outcomes heavily affect the individuals and society in terms of human suffering, loss of productivity, and health costs.

When a heavy drinker results in ApoE4-positive, a more careful clinical evaluation is needed to detect clinical symptoms and signs (if any) of ACVD. Furthermore, the patients should be advised that their risk of ACVD is increased due to both drinking habits and genetic patterns, and they should quit drinking. In alcohol-dependent subjects, abstinence should be supported by psychological and/or pharmacological treatments in specialized units.

Since most of the literature evidence that moderate alcohol drinking decreases ACVD risk and that ACVD is the main cause of death in Western countries, moderate use of alcohol could be hypothetically recommended to decrease mortality in these countries. However, clinicians should not recommend moderate drinking to prevent coronary heart disease based on this evidence alone as current NIAAA guidelines suggest a limit of one drink per day in adults $[95,180]$.

When we consider the age effect, it should be noted that in older people (over 65 years), the relationship between alcohol-ischemic stroke and alcohol-carotid thickness is modified by the ApoE genotype. Some results show that the risk among moderate drinkers is lower than abstainers ApoE4negative subjects. However, the risk among moderate drinkers is higher than abstainers among ApoE4-positive subjects. These data are worrisome and, if confirmed by further research in more extensive series and different countries, they can make alcohol abstinence mandatory for all elderly ApoE4 carriers.

The identification of ApoE genotypes may be important for pharmacological treatment. ApoE genotypes have been associated with the response of plasma lipids to lipid-lowering drugs, as statins are known to decrease LDL cholesterol levels and ACVD risk. Although the effect of Apo E gene polymorphism on the response to treatment with statins has been studied, the results are conflicting. Age and gender were found to influence low-density lipoprotein cholesterol response to a similar extent as the most pronounced genetic effects. Among SNP tested with an allele frequency of at least 5\%, only those in ApoE significantly influence statin response [181-183]. Beneficial effects of statin treatment were found in ApoE4 carriers by most authors [183-186]. Mixed or negative effects were found in a few studies [187, 188]. ApoE genotype had no significant effect on the response to treatment with atorvastatin in patients with heterozygous familial hypercholesterolemia [188].

In the future, gene therapy could be the best approach for ACVD prevention and cure. Severe hypercholesterolemia and atherosclerosis were successfully treated in ApoE deficient mice (ApoE -/-) and transgenic animals expressing an ApoE defective gene [189-191]. Promising results were also obtained using a gene therapy based on a viral vector expressing apolipoprotein A-1, which reduced atherosclerotic lesion growth in mice fed with a high-fat diet [192]. Furthermore, gene editing using the CRISP/Cas9 tech- 
nique showed substantial improvements in the atherosclerosis condition in a mouse model of hypercholesterolemia [193].

\section{LIST OF ABBREVIATIONS}

$$
\begin{aligned}
& \mathrm{ACVD}=\text { Atherosclerotic Neuro-Cardiovascular Diseases } \\
& \mathrm{ADH}=\text { Alcohol-Dehydrogenase Enzymes } \\
& \mathrm{ApoE}=\text { Apolipoprotein E } \\
& \mathrm{CETP}=\text { Cholesteryl Ester Transfer Protein } \\
& \mathrm{HDL}=\text { High-Density Lipoprotein } \\
& \mathrm{IDL}=\text { Intermediate-Density Lipoprotein } \\
& \mathrm{IL}-6=\text { Interleukin-6 } \\
& \mathrm{LDL}=\text { Low-Density Lipoprotein } \\
& \mathrm{LDLR}=\text { Low-Density Lipoprotein Receptor } \\
& \mathrm{LPL}=\text { Lipoprotein Lipase } \\
& \mathrm{VLDL}=\text { Very-Low-Density Lipoprotein }
\end{aligned}
$$

\section{CONSENT FOR PUBLICATION}

Not applicable.

\section{FUNDING}

None.

\section{CONFLICT OF INTEREST}

The authors have no conflicts of interest, financial or otherwise.

\section{ACKNOWLEDGEMENTS}

The authors thank IBBC-CNR and Sapienza University of Rome for supporting this work.

\section{REFERENCES}

[1] Ramasamy I. Recent advances in physiological lipoprotein metabolism. Clin Chem Lab Med 2014; 52(12): 1695-727. http://dx.doi.org/10.1515/cclm-2013-0358 PMID: 23940067

[2] Jonas A, Phillips MC. Lipoprotein structure. Biochem Lipids, Lipoproteins Membr 2008; 485-506.

[3] Soppert J, Lehrke M, Marx N, Jankowski J, Noels H. Lipoproteins and lipids in cardiovascular disease: from mechanistic insights to therapeutic targeting. Adv Drug Deliv Rev 2020; 159: 4-33. http://dx.doi.org/10.1016/j.addr.2020.07.019 PMID: 32730849

[4] Jones HB, Gofman JW, Lindgren FT, et al. Lipoproteins in atherosclerosis. Am J Med 1951; 11(3): 358-80. http://dx.doi.org/10.1016/0002-9343(51)90171-4 PMID 14877839

[5] Dominiczak MH, Caslake MJ. Apolipoproteins: metabolic role and clinical biochemistry applications. Ann Clin Biochem 2011; 48(Pt 6): 498-515.

http://dx.doi.org/10.1258/acb.2011.011111 PMID: 22028427

[6] Goldstein JL, Brown MS. The LDL receptor. Arterioscler Thromb Vasc Biol 2009; 29(4): 431-8 http://dx.doi.org/10.1161/ATVBAHA.108.179564 PMID: 19299327

[7] Greenow K, Pearce NJ, Ramji DP. The key role of apolipoprotein $\mathrm{E}$ in atherosclerosis. J Mol Med (Berl) 2005; 83(5): 329-42. http://dx.doi.org/10.1007/s00109-004-0631-3 PMID: 15827760
[8] Tudorache IF, Trusca VG, Gafencu AV, Apolipoprotein E. Apolipoprotein E - A Multifunctional Protein with Implications in Various Pathologies as a Result of Its Structural Features. Comput Struct Biotechnol J 2017; 15: 359-65. http://dx.doi.org/10.1016/j.csbj.2017.05.003 PMID: 28660014

[9] Chaldakov GN, Nikolov SD. Ultrastructure of the arterial smooth muscle cell. Smooth Muscle Artery New York City, NY Plenum Press. Adv Exp Med Biol 1975; 57: 14-20.

[10] Ghebranious N, Ivacic L, Mallum J, Dokken C. Detection of ApoE E2, E3 and E4 alleles using MALDI-TOF mass spectrometry and the homogeneous mass-extend technology. Nucleic Acids Res 2005; 33(17): e149. http://dx.doi.org/10.1093/nar/gni155 PMID: 16204452

[11] Matsunaga A, Saito T. Apolipoprotein E mutations: a comparison between lipoprotein glomerulopathy and type III hyperlipoproteinemia. Clin Exp Nephrol 2014; 18(2): 220-4. http://dx.doi.org/10.1007/s10157-013-0918-1 PMID: 24570178

[12] Dergunov AD. Apolipoprotein E genotype as a most significant predictor of lipid response at lipid-lowering therapy: mechanistic and clinical studies. Biomed Pharmacother 2011; 65(8): 597-603. http://dx.doi.org/10.1016/j.biopha.2011.04.003 PMID: 21705182

[13] Ceccanti M, Hamilton D, Coriale G, et al. Spatial learning in men undergoing alcohol detoxification. Physiol Behav 2015; 149: 324-30.

http://dx.doi.org/10.1016/j.physbeh.2015.06.034 PMID: 26143187

[14] Chianese R, Coccurello R, Viggiano A, et al. Impact of Dietary Fats on Brain Functions. Curr Neuropharmacol 2018; 16(7): 1059-85.

http://dx.doi.org/10.2174/1570159X15666171017102547 PMID: 29046155

[15] Chaldakov GN, Stankulov IS, Fiore M, Ghenev PI, Aloe L. Nerve growth factor levels and mast cell distribution in human coronary atherosclerosis. Atherosclerosis 2001; 159(1): 57-66.

http://dx.doi.org/10.1016/S0021-9150(01)00488-9 PMID: 11689207

[16] Chaldakov GN, Fiore M, Tonchev AB, et al. Homo obesus: a metabotrophin-deficient species. Pharmacology and nutrition insight. Curr Pharm Des 2007; 13(21): 2176-9.

http://dx.doi.org/10.2174/138161207781039616 PMID: 17627549

[17] Chaldakov GN, Fiore M, Ghenev PI, Stankulov IS, Aloe L. Atherosclerotic lesions: Possible interactive involvement of intima, adventitia and associated adipose tissue. Int Med J 2000; 7 : 43-9.

[18] Dhingra R, Vasan RS. Lipoproteins and cardiovascular disease risk. Dyslipidemias Pathophysiol Eval Manag 2015; 57-65. http://dx.doi.org/10.1007/978-1-60761-424-1_4

[19] Nelson RH. Hyperlipidemia as a Risk Factor for Cardiovascular Disease. Prim Care - Clin Off Pract 2013; 40: 195-211. http://dx.doi.org/10.1016/j.pop.2012.11.003

[20] Lichtenstein AH, Matthan NR. Cardiovascular disease. Optim Women's Heal through Nutr 2007; 199-227.

[21] Ciafre S, Fiore M, Ceccanti M, Messina MP, Tirassa P, Carito V. Role of neuropeptide tyrosine (NPY) in ethanol addiction. Biomed Rev 2016; 27: 27-39.

http://dx.doi.org/10.14748/bmr.v27.2110

[22] Ciafrè S, Carito V, Tirassa P, Ferraguti G, Attilia ML, Ciolli P, et $a l$. Ethanol consumption and innate neuroimmunity. Biomed Rev 2017; 28: 49-61

http://dx.doi.org/10.14748/bmr.v28.4451

[23] Hurtubise J, McLellan K, Durr K, Onasanya O, Nwabuko D, Ndisang JF. The different facets of dyslipidemia and hypertension in atherosclerosis. Curr Atheroscler Rep 2016; 18(12): 82 http://dx.doi.org/10.1007/s11883-016-0632-z PMID: 27822682

[24] Castelli WP. Lipids, risk factors and ischaemic heart disease. Atherosclerosis 1996; 124 (Suppl.): S1-9. http://dx.doi.org/10.1016/0021-9150(96)05851-0 PMID: 8831910

[25] Tore F, Tonchev A, Fiore M, Tuncel N, Atanassova P, Aloe L, et al. From Adipose Tissue Protein Secretion to Adipopharmacology of Disease. Immunol Endocr Metab Agents Med Chem 2007; 7 : 149-55. http://dx.doi.org/10.2174/187152207780363712

[26] Chaldakov GN, Fiore M, Tonchev AB, Aloe L. Neuroadipology: a novel component of neuroendocrinology. Cell Biol Int 2010; 
34(10): 1051-3.

http://dx.doi.org/10.1042/CBI20100509 PMID: 20825365

[27] Gordon P, Flanagan P. Smoking: A risk factor for vascular disease. J Vasc Nurs 2016; 34(3): 79-86. http://dx.doi.org/10.1016/j.jvn.2016.04.001 PMID: 27568314

[28] Hannuksela ML, Rämet ME, Nissinen AET, Liisanantti MK, Savolainen MJ. Effects of ethanol on lipids and atherosclerosis. Pathophysiology 2004; 10(2): 93-103.

http://dx.doi.org/10.1016/j.pathophys.2003.10.009 PMID: 15006415

[29] Yang W, Kang D-W, Ha SY, Lee S-H. Drinking Patterns and Risk of Ischemic Stroke in Middle-Aged Adults: Do Beneficial Drinking Habits Indeed Exist? Stroke 2021; 52(1): 164-71.

http://dx.doi.org/10.1161/STROKEAHA.120.032144 PMID: 33148143

[30] Iso H, Baba S, Mannami T, et al. Alcohol consumption and risk of stroke among middle-aged men: the JPHC Study Cohort I. Stroke 2004; 35(5): 1124-9.

http://dx.doi.org/10.1161/01.STR.0000124459.33597.00 PMID: 15017008

[31] Mostofsky E, Chahal HS, Mukamal KJ, Rimm EB, Mittleman MA. Alcohol and immediate risk of cardiovascular events. Circulation 2016; 133(10): 979-87.

http://dx.doi.org/10.1161/CIRCULATIONAHA.115.019743 PMID: 26936862

[32] Rimm EB, Williams P, Fosher K, Criqui M, Stampfer MJ. Moderate alcohol intake and lower risk of coronary heart disease: meta-analysis of effects on lipids and haemostatic factors. BMJ 1999; 319(7224): 1523-8 http://dx.doi.org/10.1136/bmj.319.7224.1523 PMID: 10591709

[33] O'Keefe JH, Bhatti SK, Bajwa A, DiNicolantonio JJ, Lavie CJ. Alcohol and cardiovascular health: the dose makes the poison... or the remedy. Mayo Clin Proc 2014; 89(3): 382-93.

http://dx.doi.org/10.1016/j.mayocp.2013.11.005 PMID: 24582196

[34] Wannamethee SG, Shaper AG. Alcohol, coronary heart disease and stroke: an examination of the J-shaped curve. Neuroepidemiology $1998 ; 17(6): 288-95$.

http://dx.doi.org/10.1159/000026182 PMID: 9778595

[35] NIAAA. Alcohol Facts and Statistics. Natl Inst Alcohol Abus Alcohol 2017.

[36] Ardic-Pulas T. Binge drinking. Aide Soignante 2016.

[37] U.S. Department of Health and Human Services and U.S. Department of Agriculture. 2015-2020 Dietary Guidelines for Americans. Diet Guidel Am (8th Ed.), 2015.

[38] Meyerhoff DJ, Bode C, Nixon SJ, de Bruin EA, Bode JC, Seitz HK. Health risks of chronic moderate and heavy alcohol consumption: how much is too much? Alcohol Clin Exp Res 2005; 29(7): 1334-40.

http://dx.doi.org/10.1097/01.ALC.0000171488.63823.09 PMID: 16088997

[39] Ceccanti M, Coccurello R, Carito V, et al. Paternal alcohol exposure in mice alters brain NGF and BDNF and increases ethanolelicited preference in male offspring. Addict Biol 2016; 21(4): 776-87.

http://dx.doi.org/10.1111/adb.12255 PMID: 25940002

[40] Ciafrè S, Carito V, Ferraguti G, et al. How alcohol drinking affects our genes: an epigenetic point of view. Biochem Cell Biol 2019; 97(4): 345-56.

http://dx.doi.org/10.1139/bcb-2018-0248 PMID: 30412425

[41] Ferraguti G, Merlino L, Battagliese G, et al. Fetus morphology changes by second-trimester ultrasound in pregnant women drinking alcohol. Addict Biol 2020; 25(3): e12724.

http://dx.doi.org/10.1111/adb.12724 PMID: 30811093

[42] Ferraguti G, Ciolli P, Carito V, et al. Ethylglucuronide in the urine as a marker of alcohol consumption during pregnancy: Comparison with four alcohol screening questionnaires. Toxicol Lett 2017; 275: 49-56.

http://dx.doi.org/10.1016/j.toxlet.2017.04.016 PMID: 28455000

[43] Coriale G, Fiorentino D, Di Lauro F, et al. Fetal Alcohol Spectrum Disorder (FASD): neurobehavioral profile, indications for diagnosis and treatment. Riv Psichiatr 2013; 48(5): 359-69.

http://dx.doi.org/10.1708/1356.15062 PMID: 24326748

[44] Ogunmoroti O, Osibogun O, McClelland RL, et al. Alcohol type and ideal cardiovascular health among adults of the Multi-Ethnic Study of Atherosclerosis. Drug Alcohol Depend 2021; 218: 108358 .

http://dx.doi.org/10.1016/j.drugalcdep.2020.108358 PMID: 33162252

[45] Petrella C, Farioli-Vecchioli S, Cisale GY, et al. A healthy gut for a healthy brain: preclinical, clinical and regulatory aspects. Curr Neuropharmacol 2020; $\cdots$

http://dx.doi.org/10.2174/1570159X18666200730111528 PMID: 32744976

[46] Ceccanti M, Coriale G, Hamilton DA, et al. Virtual Morris task responses in individuals in an abstinence phase from alcohol. Can J Physiol Pharmacol 2018; 96(2): 128-36.

http://dx.doi.org/10.1139/cjpp-2017-0013 PMID: 28763626

[47] Jani BD, McQueenie R, Nicholl BI, et al. Association between patterns of alcohol consumption (beverage type, frequency and consumption with food) and risk of adverse health outcomes: a prospective cohort study. BMC Med 2021; 19(1): 8

http://dx.doi.org/10.1186/s12916-020-01878-2 PMID: 33430840

[48] Piano MR, Mazzuco A, Kang M, Phillips SA. Cardiovascular Consequences of Binge Drinking: An Integrative Review with Implications for Advocacy, Policy, and Research. Alcohol Clin Exp Res 2017; 41(3): 487-96.

http://dx.doi.org/10.1111/acer.13329 PMID: 28067964

[49] Gardner JD, Mouton AJ. Alcohol effects on cardiac function. Compr Physiol 2015; 5(2): 791-802.

http://dx.doi.org/10.1002/cphy.c140046 PMID: 25880513

[50] Carito V, Ceccanti M, Tarani L, Ferraguti G, Chaldakov GN Fiore M. Neurotrophins' Modulation by Olive Polyphenols. Curr Med Chem 2016; 23(28): 3189-97.

http://dx.doi.org/10.2174/0929867323666160627104022 PMID: 27356540

[51] Carito V, Ciafrè S, Tarani L, et al. TNF- $\alpha$ and IL-10 modulation induced by polyphenols extracted by olive pomace in a mouse model of paw inflammation. Ann Ist Super Sanita 2015; 51(4): 382-6.

http://dx.doi.org/10.4415/ANN-15-04-21 PMID: 26783228

[52] Fiore M, Messina MP, Petrella C, D’Angelo A, Greco A, Ralli M, et al. Antioxidant properties of plant polyphenols in the counteraction of alcohol-abuse induced damage: Impact on the Mediterranean diet. J Funct Foods 2020; 71: 104012. http://dx.doi.org/10.1016/j.jff.2020.104012

[53] Petrella C, Carito V, Carere C, Ferraguti G, Ciafrè S, Natella F, et al. Oxidative stress inhibition by resveratrol in alcohol dependent mice. Nutrition, 2020 http://dx.doi.org/10.1016/j.nut.2020.110783

[54] Carito V, Ceccanti M, Cestari V, et al. Olive polyphenol effects in a mouse model of chronic ethanol addiction. Nutrition 2017; 33: $65-9$.

http://dx.doi.org/10.1016/j.nut.2016.08.014 PMID: 27908553

[55] Magrone T, Tafaro A, Jirillo F, et al. Red wine consumption and prevention of atherosclerosis: an in vitro model using human peripheral blood mononuclear cells. Curr Pharm Des 2007; 13(36): 3718-25.

http://dx.doi.org/10.2174/138161207783018581 PMID: 18220811

[56] Szmitko PE, Verma S. Antiatherogenic potential of red wine: Clinician update. Am J Physiol - Hear Circ Physiol, 2005.

[57] Zoratto F, Fiore M, Ali SF, Laviola G, Macrì S. Neonatal tryptophan depletion and corticosterone supplementation modify emotional responses in adult male mice. Psychoneuroendocrinology 2013; 38(1): 24-39.

http://dx.doi.org/10.1016/j.psyneuen.2012.04.015 PMID: 22613034

[58] Zoratto F, Berry A, Anzidei F, et al. Effects of maternal L-tryptophan depletion and corticosterone administration on neurobehavioral adjustments in mouse dams and their adolescent and adult daughters. Prog Neuropsychopharmacol Biol Psychiatry 2011; 35(6): 1479-92. http://dx.doi.org/10.1016/j.pnpbp.2011.02.016 PMID: 21356262

[59] Laviola G, Zoratto F, Ingiosi D, et al. Low empathy-like behaviour in male mice associates with impaired sociability, emotional memory, physiological stress reactivity and variations in neurobiological regulations. PLoS One 2017; 12(12): e0188907. 
http://dx.doi.org/10.1371/journal.pone.0188907 PMID: 29200428

[60] Carito V, Venditti A, Bianco A, et al. Effects of olive leaf polyphenols on male mouse brain NGF, BDNF and their receptors TrkA, TrkB and p75. Nat Prod Res 2014; 28(22): 1970-84 http://dx.doi.org/10.1080/14786419.2014.918977 PMID 24865115

[61] Angelucci F, Fiore M, Cozzari C, Aloe L. Prenatal ethanol effects on NGF level, NPY and ChAT immunoreactivity in mouse entorhinal cortex: a preliminary study. Neurotoxicol Teratol 1999; 21(4): 415-25.

http://dx.doi.org/10.1016/S0892-0362(99)00005-7 PMID: 10440485

[62] Fiore M, Mancinelli R, Aloe L, et al. Hepatocyte growth factor, vascular endothelial growth factor, glial cell-derived neurotrophic factor and nerve growth factor are differentially affected by early chronic ethanol or red wine intake. Toxicol Lett 2009; 188(3): 208-13.

http://dx.doi.org/10.1016/j.toxlet.2009.04.013 PMID: 19397965

[63] Fiore M, Laviola G, Aloe L, di Fausto V, Mancinelli R, Ceccanti M. Early exposure to ethanol but not red wine at the same alcohol concentration induces behavioral and brain neurotrophin alterations in young and adult mice. Neurotoxicology 2009; 30(1): 59-71.

http://dx.doi.org/10.1016/j.neuro.2008.11.009 PMID: 19100286

[64] Ceccanti M, Mancinelli R, Tirassa P, et al. Early exposure to ethanol or red wine and long-lasting effects in aged mice. A study on nerve growth factor, brain-derived neurotrophic factor, hepatocyte growth factor, and vascular endothelial growth factor. Neurobiol Aging 2012; 33(2): 359-67.

http://dx.doi.org/10.1016/j.neurobiolaging.2010.03.005 PMID: 20382450

[65] Emamian M, Avan A, Pasdar A, et al. The lipoprotein lipase S447X and cholesteryl ester transfer protein rs5882 polymorphisms and their relationship with lipid profile in human serum of obese individuals. Gene 2015; 558(2): 195-9.

http://dx.doi.org/10.1016/j.gene.2014.12.070 PMID: 25579610

[66] Lee J, Tan CS, Chia KS, et al. The lipoprotein lipase S447X polymorphism and plasma lipids: interactions with APOE polymorphisms, smoking, and alcohol consumption. J Lipid Res 2004; 45(6): 1132-9.

http://dx.doi.org/10.1194/jlr.M400016-JLR200 PMID: 15060087

[67] Baik I, Lee S, Kim SH, Shin C. A lipoprotein lipase gene polymorphism interacts with consumption of alcohol and unsaturated fat to modulate serum HDL-cholesterol concentrations. J Nutr 2013; 143(10): $1618-25$

http://dx.doi.org/10.3945/jn.113.175315 PMID: 23902956

[68] Marais AD. Apolipoprotein E in lipoprotein metabolism, health and cardiovascular disease. Pathology 2019; 51(2): 165-76. http://dx.doi.org/10.1016/j.pathol.2018.11.002 PMID: 30598326

[69] Mahley RW. Apolipoprotein E: from cardiovascular disease to neurodegenerative disorders. J Mol Med (Berl) 2016; 94(7): $739-46$

http://dx.doi.org/10.1007/s00109-016-1427-y PMID: 27277824

[70] Zhu H, Xue H, Wang H, Ma Y, Liu J, Chen Y. The association of apolipoprotein E (APOE) gene polymorphisms with atherosclerosis susceptibility: a meta-analysis. Minerva Cardioangiol 2016; 64(1): 47-54.

PMID: 26005211

[71] Anoop S, Misra A, Meena K, Luthra K. Apolipoprotein E polymorphism in cerebrovascular \& coronary heart diseases. Indian $\mathrm{J}$ Med Res 2010; 132: 363-78.

PMID: 20966513

[72] Zhao QR, Lei YY, Li J, Jiang N, Shi JP. Association between apolipoprotein E polymorphisms and premature coronary artery disease: a meta-analysis. Clin Chem Lab Med 2017; 55(2): 284-98.

http://dx.doi.org/10.1515/cclm-2016-0145 PMID: 27394044

[73] Chen H, Ding S, Liu X, Wu Y, Wu X. Association of Interleukin-6 Genetic Polymorphisms and Environment Factors Interactions with Coronary Artery Disease in a Chinese Han Population. Clin Exp Hypertens 2018; 40(6): 514-7.

http://dx.doi.org/10.1080/10641963.2017.1403618 PMID: 29889576
[74] Hou H, Wang C, Sun F, Zhao L, Dun A, Sun Z. Association of interleukin-6 gene polymorphism with coronary artery disease: an updated systematic review and cumulative meta-analysis. Inflamm Res 2015; 64(9): 707-20. http://dx.doi.org/10.1007/s00011-015-0850-9 PMID: 26174156

[75] Wall TL, Luczak SE, Hiller-Sturmhöfel S. Biology, genetics, and environment: Underlying factors influencing alcohol metabolism. Alcohol Res 2016; 38(1): 59-68.

PMID: 27163368

[76] Lee YJ, Yoo MG, Kim HK, et al. The association between alcohol metabolism and genetic variants of ADH1A, SRPRB, and PGM1 in Korea. Alcohol 2019; 79: 137-45. http://dx.doi.org/10.1016/j.alcohol.2019.03.004 PMID: 31002879

[77] Hines LM, Stampfer MJ, Ma J, et al. Genetic variation in alcohol dehydrogenase and the beneficial effect of moderate alcohol consumption on myocardial infarction. N Engl J Med 2001; 344(8): 549-55.

http://dx.doi.org/10.1056/NEJM200102223440802 PMID: 11207350

[78] Drogan D, Sheldrick AJ, Schütze M, et al. Alcohol consumption, genetic variants in alcohol deydrogenases, and risk of cardiovascular diseases: a prospective study and meta-analysis. PLoS One 2012; 7(2): e32176.

http://dx.doi.org/10.1371/journal.pone.0032176 PMID: 22363810

[79] Tolstrup JS, Grønbaek M, Nordestgaard BG. Alcohol intake, myocardial infarction, biochemical risk factors, and alcohol dehydrogenase genotypes. Circ Cardiovasc Genet 2009; 2(5): 507-14.

http://dx.doi.org/10.1161/CIRCGENETICS.109.873604 PMID: 20031627

[80] Huang Y, Mahley RW, Apolipoprotein E. Apolipoprotein E: structure and function in lipid metabolism, neurobiology, and Alzheimer's diseases. Neurobiol Dis 2014; 72(Pt A): 3-12. http://dx.doi.org/10.1016/j.nbd.2014.08.025 PMID: 25173806

[81] Han S, Xu Y, Gao M, et al. Serum apolipoprotein E concentration and polymorphism influence serum lipid levels in Chinese Shandong Han population. Medicine (Baltimore) 2016; 95(50): e5639. http://dx.doi.org/10.1097/MD.0000000000005639 PMID: 27977609

[82] Rasmussen KL. Plasma levels of apolipoprotein E, APOE genotype and risk of dementia and ischemic heart disease: A review. Atherosclerosis 2016; 255: 145-55.

http://dx.doi.org/10.1016/j.atherosclerosis.2016.10.037 PMID: 28340945

[83] Bennet AM, Di Angelantonio E, Ye Z, et al. Association of apolipoprotein $\mathrm{E}$ genotypes with lipid levels and coronary risk. JAMA 2007; 298(11): 1300-11.

http://dx.doi.org/10.1001/jama.298.11.1300 PMID: 17878422

[84] Granér M, Kahri J, Varpula M, et al. Apolipoprotein E polymorphism is associated with both carotid and coronary atherosclerosis in patients with coronary artery disease. Nutr Metab Cardiovasc Dis $2008 ; 18(4): 271-7$. http://dx.doi.org/10.1016/j.numecd.2007.01.003 PMID: 17462871

[85] Luo JQ, Ren H, Banh HL, et al. The associations between apolipoprotein E gene epsilon2/epsilon3/epsilon4 polymorphisms and the risk of coronary artery disease in patients with type 2 diabetes mellitus. Front Physiol 2017; 8: 1031. http://dx.doi.org/10.3389/fphys.2017.01031 PMID: 29311965

[86] Jensen MK, Mukamal KJ, Overvad K, Rimm EB. Alcohol consumption, TaqIB polymorphism of cholesteryl ester transfer protein, high-density lipoprotein cholesterol, and risk of coronary heart disease in men and women. Eur Heart J 2008; 29(1): 104-12. http://dx.doi.org/10.1093/eurheartj/ehm517 PMID: 18063597

[87] Mäkelä SM, Jauhiainen M, Ala-Korpela M, et al. HDL2 of heavy alcohol drinkers enhances cholesterol efflux from raw macrophages via phospholipid-rich HDL $2 \mathrm{~b}$ particles. Alcohol Clin Exp Res 2008; 32(6): 991-1000.

http://dx.doi.org/10.1111/j.1530-0277.2008.00660.x PMID: 18498551

[88] Zheng KQ, Zhang SZ, He Y, et al. Association between cholesteryl ester transfer protein gene polymorphisms and variations in lipid levels in patients with coronary heart disease. Chin Med J (Engl) 2004; 117(9): 1288-92. PMID: 15377415 
[89] Huang Y, Li Y, Zheng S, Yang X, Wang T, Zeng J. Moderate alcohol consumption and atherosclerosis : Meta-analysis of effects on lipids and inflammation. Wien Klin Wochenschr 2017; 129(21-22): 835-43. http://dx.doi.org/10.1007/s00508-017-1235-6 PMID: 28762059

[90] Kováŕ J, Zemánková K. Moderate alcohol consumption and triglyceridemia. Physiol Res 2015; 64 (Suppl. 3): S371-5. http://dx.doi.org/10.33549/physiolres.933178 PMID: 26680670

[91] Vu KN, Ballantyne CM, Hoogeveen RC, et al. Causal role of alcohol consumption in an improved lipid profile: The atherosclerosis risk in communities (aric) study. PLoS One 2016; 11(2): e0148765. http://dx.doi.org/10.1371/journal.pone.0148765 PMID: 26849558

[92] Brinton EA. Effects of ethanol intake on lipoproteins. Curr Atheroscler Rep 2012; 14(2): 108-14. http://dx.doi.org/10.1007/s11883-012-0230-7 PMID: 22350634

[93] Brien SE, Ronksley PE, Turner BJ, Mukamal KJ, Ghali WA. Effect of alcohol consumption on biological markers associated with risk of coronary heart disease: systematic review and meta-analysis of interventional studies. BMJ 2011; 342: d636. http://dx.doi.org/10.1136/bmj.d636 PMID: 21343206

[94] Muth ND, Laughlin GA, von Mühlen D, Smith SC, Barrett-Connor E. High-density lipoprotein subclasses are a potential intermediary between alcohol intake and reduced risk of cardiovascular disease: the Rancho Bernardo Study. Br J Nutr 2010; 104(7): 1034-42. http://dx.doi.org/10.1017/S0007114510001595 PMID: 20426890

[95] Chiva-Blanch G, Badimon L. Benefits and risks of moderate alcohol consumption on cardiovascular disease: Current findings and controversies. Nutrients 2019; 12(1): E108.

http://dx.doi.org/10.3390/nu12010108 PMID: 31906033

[96] He PP, Jiang T, OuYang XP, et al. Lipoprotein lipase: Biosynthesis, regulatory factors, and its role in atherosclerosis and other diseases. Clin Chim Acta 2018; 480: 126-37. http://dx.doi.org/10.1016/j.cca.2018.02.006 PMID: 29453968

[97] Nova E, San Mauro-Martín I, Díaz-Prieto LE, Marcos A. Wine and beer within a moderate alcohol intake is associated with higher levels of HDL-c and adiponectin. Nutr Res 2019; 63: 42-50. http://dx.doi.org/10.1016/j.nutres.2018.12.007 PMID: 30824396

[98] Beulens JWJ, de Zoete EC, Kok FJ, Schaafsma G, Hendriks HFJ. Effect of moderate alcohol consumption on adipokines and insulin sensitivity in lean and overweight men: a diet intervention study. Eur J Clin Nutr 2008; 62(9): 1098-105.

http://dx.doi.org/10.1038/sj.ejcn.1602821 PMID: 17554246

[99] Fujishima Y, Maeda N, Matsuda K, et al. Adiponectin association with $\mathrm{T}$-cadherin protects against neointima proliferation and atherosclerosis. FASEB J 2017; 31(4): 1571-83.

http://dx.doi.org/10.1096/fj.201601064R PMID: 28062540

[100] Katsiki N, Mantzoros C, Mikhailidis DP. Adiponectin, lipids and atherosclerosis. Curr Opin Lipidol 2017; 28(4): 347-54. http://dx.doi.org/10.1097/MOL.0000000000000431 PMID 28463859

[101] Zhang L, Yan F, Zhang S, et al. Structural basis of transfer between lipoproteins by cholesteryl ester transfer protein. Nat Chem Biol 2012; 8(4): 342-9.

http://dx.doi.org/10.1038/nchembio.796 PMID: 22344176

[102] Shrestha S, Wu BJ, Guiney L, Barter PJ, Rye KA. Cholesteryl ester transfer protein and its inhibitors. J Lipid Res 2018; 59(5): 772-83.

http://dx.doi.org/10.1194/jlr.R082735 PMID: 29487091

[103] Gaubatz JW, Gillard BK, Rosales C, Pownall HJ. Dietary Alcohol and Fat Differentially Affect Plasma Cholesteryl Ester Transfer Activity and Triglycerides in Normo- and Hypertriglyceridemic Subjects. Lipids 2020; 55(4): 299-307.

http://dx.doi.org/10.1002/lipd.12237 PMID: 32255209

[104] Wu BJ, Shrestha S, Ong KL, et al. Cholesteryl ester transfer protein inhibition enhances endothelial repair and improves endothelial function in the rabbit. Arterioscler Thromb Vasc Biol 2015; 35(3): 628-36.

http://dx.doi.org/10.1161/ATVBAHA.114.304747 PMID: 25633313

[105] Rantakömi SH, Laukkanen JA, Kurl S, Kauhanen J. Binge drinking and the progression of atherosclerosis in middle-aged men: an 11-year follow-up. Atherosclerosis 2009; 205(1): 266-71. http://dx.doi.org/10.1016/j.atherosclerosis.2008.11.004 PMID: 19108835

[106] Toma A, Paré G, Leong DP. Alcohol and Cardiovascular Disease: How Much is Too Much? Curr Atheroscler Rep 2017; 19(3): 13. http://dx.doi.org/10.1007/s11883-017-0647-0 PMID: 28210975

[107] Piano MR, Burke L, Kang M, Phillips SA. Effects of repeated binge drinking on blood pressure levels and other cardiovascular health metrics in young adults: National health and Nutrition Examination Survey, 2011-2014. J Am Heart Assoc 2018; 7(13): e008733.

http://dx.doi.org/10.1161/JAHA.118.008733 PMID: 29950486

[108] Zemánková K, Makoveichuk E, Vlasáková Z, Olivecrona G, Kováŕ J. Acute alcohol consumption downregulates lipoprotein lipase activity in vivo. Metabolism 2015; 64(11): 1592-6.

http://dx.doi.org/10.1016/j.metabol.2015.08.016 PMID: 26388538

[109] Tanaka A, Cui R, Kitamura A, et al. Heavy alcohol consumption is associated with impaired endothelial function: The circulatory risk in communities study (CIRCS). J Atheroscler Thromb 2016; 23(9): 1047-54.

http://dx.doi.org/10.5551/jat.31641 PMID: 27025680

[110] Waśkiewicz A, Sygnowska E. Alcohol intake and cardiovascular risk factor profile in men participating in the WOBASZ study. Kardiol Pol 2013; 71(4): 359-65.

http://dx.doi.org/10.5603/KP.2013.0063 PMID: 23788341

[111] Cho JY, Choi J, Park JG, et al. Alcohol-induced hyperlipidemia is ameliorated by orally administered DWP208, a sodium succinate form of ZYM201. Korean J Physiol Pharmacol 2014; 18(6): 469-74.

http://dx.doi.org/10.4196/kjpp.2014.18.6.469 PMID: 25598660

[112] Chait A, Mancini M, February AW. A clinical and metabolic study of alcoholic hyperlipidaemia. Lancet 1972.

[113] Piano MR, Phillips SA. Alcoholic cardiomyopathy: pathophysiologic insights. Cardiovasc Toxicol 2014; 14(4): 291-308. http://dx.doi.org/10.1007/s12012-014-9252-4 PMID: 24671642

[114] Peluso I, Morabito G, Urban L, Ioannone F, Serafini M. Oxidative stress in atherosclerosis development: the central role of LDL and oxidative burst. Endocr Metab Immune Disord Drug Targets 2012; 12(4): 351-60.

http://dx.doi.org/10.2174/187153012803832602 PMID: 23061409

[115] Miller YI, Choi SH, Fang L, Tsimikas S. Lipoprotein modification and macrophage uptake: role of pathologic cholesterol transport in atherogenesis. Subcell Biochem 2010; 51: 229-51. http://dx.doi.org/10.1007/978-90-481-8622-8 8 PMID: 20213546

[116] Ciafrè S, Ferraguti G, Greco A, et al. Alcohol as an early life stressor: Epigenetics, metabolic, neuroendocrine and neurobehavioral implications. Neurosci Biobehav Rev 2020; 118: 654-68.

http://dx.doi.org/10.1016/j.neubiorev.2020.08.018 PMID: 32976915

[117] Chistiakov DA, Melnichenko AA, Myasoedova VA, Grechko AV, Orekhov AN. Mechanisms of foam cell formation in atherosclerosis. J Mol Med (Berl) 2017; 95(11): 1153-65.

http://dx.doi.org/10.1007/s00109-017-1575-8 PMID: 28785870

[118] Alique M, Luna C, Carracedo J, Ramírez R. LDL biochemical modifications: a link between atherosclerosis and aging. Food $\mathrm{Nu}-$ tr Res 2015; 59: 29240.

http://dx.doi.org/10.3402/fnr.v59.29240 PMID: 26637360

[119] Getz GS, Reardon CA. Apoprotein E and reverse cholesterol transport. Int J Mol Sci 2018; 19(11): E3479.

http://dx.doi.org/10.3390/ijms19113479 PMID: 30404132

[120] Bouchareychas L, Raffai RL. Apolipoprotein E and Atherosclerosis: From Lipoprotein Metabolism to MicroRNA Control of Inflammation. J Cardiovasc Dev Dis 2018; 5(2): 30. http://dx.doi.org/10.3390/jcdd5020030 PMID: 29789495

[121] Huebbe P, Rimbach G. Evolution of human apolipoprotein E (APOE) isoforms: Gene structure, protein function and interaction with dietary factors. Ageing Res Rev 2017; 37: 146-61. http://dx.doi.org/10.1016/j.arr.2017.06.002 PMID: 28647612

[122] Pereira LC, Nascimento JCR, Rêgo JMC, et al. Apolipoprotein E, periodontal disease and the risk for atherosclerosis: a review. Arch Oral Biol 2019; 98: 204-12.

http://dx.doi.org/10.1016/j.archoralbio.2018.11.009 PMID: 30503976 
[123] Mendes-Lana A, Pena GG, Freitas SN, et al. Apolipoprotein E polymorphism in Brazilian dyslipidemic individuals: Ouro Preto study. Braz J Med Biol Res 2007; 40(1): 49-56.

http://dx.doi.org/10.1590/S0100-879X2007000100007 PMID: 17224996

[124] Riemenschneider M, Schwarz S, Wagenpfeil S, et al. A polymorphism of the brain-derived neurotrophic factor (BDNF) is associated with Alzheimer's disease in patients lacking the Apolipoprotein E epsilon4 allele. Mol Psychiatry 2002; 7(7): 782-5. http://dx.doi.org/10.1038/sj.mp.4001073 PMID: 12192623

[125] Yin Y, Wang Z. ApoE and neurodegenerative diseases in aging. Adv Exp Med Biol 2018; 1086: 77-92. http://dx.doi.org/10.1007/978-981-13-1117-8 5

[126] Heeren J, Grewal T, Laatsch A, et al. Impaired recycling of apolipoprotein E4 is associated with intracellular cholesterol accumulation. J Biol Chem 2004; 279(53): 55483-92.

http://dx.doi.org/10.1074/jbc.M409324200 PMID: 15485881

[127] Correa Leite ML, Moriguchi EH, Lima-Costa MF. Effects of interactions between ApoE polymorphisms, alcohol consumption and obesity on age-related trends of blood pressure levels in postmenopausal women: the Bambuì cohort study of aging (1997-2008). Maturitas 2013; 76(1): 57-63.

http://dx.doi.org/10.1016/j.maturitas.2013.05.012 PMID: 23773371

[128] Ning B, Chen Y, Waqar AB, et al. Hypertension Enhances Advanced Atherosclerosis and Induces Cardiac Death in Watanabe Heritable Hyperlipidemic Rabbits. Am J Pathol 2018; 188(12): 2936-47.

http://dx.doi.org/10.1016/j.ajpath.2018.08.007 PMID: 30248339

[129] Liu CC, Liu CC, Kanekiyo T, Xu H, Bu G. Apolipoprotein E and Alzheimer disease: risk, mechanisms and therapy. Nat Rev Neurol 2013; 9(2): 106-18.

http://dx.doi.org/10.1038/nrneurol.2012.263 PMID: 23296339

[130] Hersi M, Irvine B, Gupta P, Gomes J, Birkett N, Krewski D. Risk factors associated with the onset and progression of Alzheimer's disease: A systematic review of the evidence. Neurotoxicology 2017; 61: 143-87.

http://dx.doi.org/10.1016/j.neuro.2017.03.006 PMID: 28363508

[131] Burman D, Mente A, Hegele RA, Islam S, Yusuf S, Anand SS. Relationship of the ApoE polymorphism to plasma lipid traits among South Asians, Chinese, and Europeans living in Canada. Atherosclerosis 2009; 203(1): 192-200.

http://dx.doi.org/10.1016/j.atherosclerosis.2008.06.007 PMID: 18656198

[132] Sakuma N, Hibino T, Saeki T, et al. Compound heterozygotes for a novel mutation, apo E1 Nagoya (Arg142Ser) and Apo E2 (Arg158Cys), with severe type III hyperlipoproteinemia and familial hypercholesterolemia. J Atheroscler Thromb 2014; 21(9): 983-8.

http://dx.doi.org/10.5551/jat.21394 PMID: 24953047

[133] Yu J-T, Tan L, Hardy J. Apolipoprotein E in Alzheimer's disease: an update. Annu Rev Neurosci 2014; 37: 79-100.

http://dx.doi.org/10.1146/annurev-neuro-071013-014300 PMID: 24821312

[134] Castellano JM, Kim J, Stewart FR, et al. Human apoE isoforms differentially regulate brain amyloid- $\beta$ peptide clearance. Sci Transl Med 2011; 3(89): 89ra57.

http://dx.doi.org/10.1126/scitranslmed.3002156 PMID: 21715678

[135] Deanfield JE, Halcox JP, Rabelink TJ. Endothelial function and dysfunction: testing and clinical relevance. Circulation 2007; 115(10): 1285-95.

http://dx.doi.org/10.1161/CIRCULATIONAHA.106.652859 PMID: 17353456

[136] Ras RT, Streppel MT, Draijer R, Zock PL. Flow-mediated dilation and cardiovascular risk prediction: a systematic review with meta-analysis. Int J Cardiol 2013; 168(1): 344-51.

http://dx.doi.org/10.1016/j.ijcard.2012.09.047 PMID: 23041097

[137] Piano MR. Alcohol's Effects on the Cardiovascular System. Alcohol Res 2017; 38(2): 219-41.

PMID: 28988575

[138] Förstermann U, Xia N, Li H. Roles of vascular oxidative stress and nitric oxide in the pathogenesis of atherosclerosis. Circ Res 2017; 120(4): 713-35.
http://dx.doi.org/10.1161/CIRCRESAHA.116.309326 PMID: 28209797

[139] Piccarducci R, Daniele S, Fusi J, et al. Impact of ApoE polymorphism and physical activity on plasma antioxidant capability and erythrocyte membranes. Antioxidants 2019; 8(11): E538.

http://dx.doi.org/10.3390/antiox8110538 PMID: 31717561

[140] Yuan L, Liu J, Dong L, et al. Effects of APOE rs429358, rs7412 and GSTM1/GSTT1 polymorphism on plasma and erythrocyte antioxidant parameters and cognition in old Chinese adults. Nutrients 2015; 7(10): 8261-73.

http://dx.doi.org/10.3390/nu7105391 PMID: 26404360

[141] Ceci FM, Ferraguti G, Petrella C, Greco A, Ralli M, Iannitelli A, et al. Nerve Growth Factor in Alcohol Use Disorders. Curr Neuropharmacol 2020; 18

http://dx.doi.org/10.2174/1570159x18666200429003239 PMID: 32348226

[142] Rosoff DB, Charlet K, Jung J, et al. Association of High-Intensity Binge Drinking With Lipid and Liver Function Enzyme Levels. JAMA Netw Open 2019;2(6): e195844.

http://dx.doi.org/10.1001/jamanetworkopen.2019.5844 PMID: 31199452

[143] Orio L, Antón M, Rodríguez-Rojo IC, et al. Young alcohol binge drinkers have elevated blood endotoxin, peripheral inflammation and low cortisol levels: neuropsychological correlations in women. Addict Biol 2018; 23(5): 1130-44.

http://dx.doi.org/10.1111/adb.12543 PMID: 28840951

[144] Laguzzi F, Baldassarre D, Veglia F, Strawbridge RJ, Humphries $\mathrm{SE}$, Rauramaa R, et al. Alcohol consumption in relation to carotid subclinical atherosclerosis and its progression: results from a European longitudinal multicentre study. Eur J Nutr 2020; ••• http://dx.doi.org/10.1007/s00394-020-02220-5 PMID: 32206896

[145] Bell S, Mehta G, Moore K, Britton A. Ten-year alcohol consumption typologies and trajectories of C-reactive protein, interleukin-6 and interleukin-1 receptor antagonist over the following 12 years: a prospective cohort study. J Intern Med 2017; 281(1): 75-85. http://dx.doi.org/10.1111/joim.12544 PMID: 27485145

[146] Marques-Vidal P, Bochud M, Bastardot F, et al. Associations between alcohol consumption and selected cytokines in a Swiss population-based sample (CoLaus study). Atherosclerosis 2012; 222(1): 245-50.

http://dx.doi.org/10.1016/j.atherosclerosis.2012.02.011 PMID: 22420891

[147] Geovanini GR, Libby P. Atherosclerosis and inflammation: overview and updates. Clin Sci (Lond) 2018; 132(12): 1243-52. http://dx.doi.org/10.1042/CS20180306 PMID: 29930142

[148] Hartman J, Frishman WH. Inflammation and atherosclerosis: a review of the role of interleukin- 6 in the development of atherosclerosis and the potential for targeted drug therapy. Cardiol Rev 2014; 22(3): 147-51.

http://dx.doi.org/10.1097/CRD.0000000000000021 PMID: 24618929

[149] Wang X, Li W, Hao L, et al. The therapeutic potential of CETP inhibitors: a patent review. Expert Opin Ther Pat 2018; 28(4): 331-40.

http://dx.doi.org/10.1080/13543776.2018.1439476 PMID: 29424255

[150] Di Bartolo B, Takata K, Duong M, Nicholls SJ. CETP Inhibition in CVD Prevention: an Actual Appraisal. Curr Cardiol Rep 2016; 18(5): 43 .

http://dx.doi.org/10.1007/s11886-016-0724-y PMID: 27002619

[151] Yamashita S, Matsuzawa Y. Re-evaluation of cholesteryl ester transfer protein function in atherosclerosis based upon genetics and pharmacological manipulation. Curr Opin Lipidol 2016; 27(5): 459-72.

http://dx.doi.org/10.1097/MOL.0000000000000332 PMID: 27454452

[152] Okada T, Ohama T, Okazaki M, et al. Particle number analysis of lipoprotein subclasses by gel permeation HPLC in patients with cholesteryl ester transfer protein deficiency. PLoS One 2018; 13(1): e0190875.

http://dx.doi.org/10.1371/journal.pone.0190875 PMID: 29304079

[153] Srirojnopkun C, Kietrungwilaikul K, Boonsong K, Thongpoonkaew J, Jeenduang N. Association of APOE and CETP 
TaqIB Polymorphisms with Type 2 Diabetes Mellitus. Arch Med Res 2018; 49(7): 479-85. http://dx.doi.org/10.1016/j.arcmed.2019.02.005 PMID: 30853126

[154] Włodarczyk M, Wrzosek M, Nowicka G, Jabłonowska-Lietz B. Impact of variants in CETP and apo AI genes on serum HDL cholesterol levels in men and women from the Polish population. Arch Med Sci 2016; 12(6): 1188-98. http://dx.doi.org/10.5114/aoms.2016.60870 PMID: 27904507

[155] Tall AR, Rader DJ. Trials and Tribulations of CETP Inhibitors. Circ Res 2018; 122(1): 106-12.

http://dx.doi.org/10.1161/CIRCRESAHA.117.311978 PMID: 29018035

[156] Masson W, Lobo M, Siniawski D, et al. Therapy with cholesteryl ester transfer protein (CETP) inhibitors and diabetes risk. Diabetes Metab 2018; 44(6): 508-13.

http://dx.doi.org/10.1016/j.diabet.2018.02.005 PMID: 29523487

[157] Chen DW, Jin Y, Zhao RM, et al. Age-, sex- and glucose-dependent correlation of plasma soluble vascular adhesion protein-1 concentration with cardiovascular risk factors and subclinical atherosclerosis. Eur Rev Med Pharmacol Sci 2016; 20(8): 1544-58. http://dx.doi.org/10.1016/j.atherosclerosis.2015.04.786 PMID: 27160127

[158] Darke S, Duflou J, Kaye S, Farrell M, Lappin J. Body mass index and fatal stroke in young adults: A national study. J Forensic Leg Med 2019; 63: 1-6.

http://dx.doi.org/10.1016/j.jflm.2019.02.003 PMID: 30822741

[159] Qu B, Qu T, Liu Y, et al. Risk Factors Associated With Increased Carotid Intima-Media Thickness in a Male Population With Chronic Alcohol Consumption: A Prospective Observational Study. Medicine (Baltimore) 2016; 95(15): e3322.

http://dx.doi.org/10.1097/MD.0000000000003322 PMID: 27082578

[160] Singhrao SK, Harding A, Chukkapalli S, Olsen I, Kesavalu L, Crean S. Apolipoprotein e related co-morbidities and Alzheimer's disease. J Alzheimers Dis 2016; 51(4): 935-48.

http://dx.doi.org/10.3233/JAD150690 PMID: 26923007

[161] Clarkson TB. Estrogen effects on arteries vary with stage of reproductive life and extent of subclinical atherosclerosis progression. Menopause 2018; 25(11): 1262-74.

http://dx.doi.org/10.1097/GME.0000000000001228 PMID: 30358722

[162] Li H, Mani S, Wu L, Fu M, Shuang T, Xu C, et al. The interaction of estrogen and CSE/H2S pathway in the development of atherosclerosis. Am J Physiol - Hear Circ Physiol 2017; 312: 406-14.

[163] Dam MK, Hvidtfeldt UA, Tjønneland A, Overvad K, Grønbæk M, Tolstrup JS. Five year change in alcohol intake and risk of breast cancer and coronary heart disease among postmenopausal women: prospective cohort study. BMJ 2016; 353: i2314. http://dx.doi.org/10.1136/bmj.i2314 PMID: 27169583

[164] Ogunmoroti O, Osibogun O, McClelland RL, Burke GL, Nasir K, Michos ED. Alcohol and ideal cardiovascular health: The Multi-Ethnic Study of Atherosclerosis. Clin Cardiol 2019; 42(1): 151-8. http://dx.doi.org/10.1002/clc.23125 PMID: 30506744

[165] Frezza M, di Padova C, Pozzato G, Terpin M, Baraona E, Lieber CS. High blood alcohol levels in women. The role of decreased gastric alcohol dehydrogenase activity and first-pass metabolism. N Engl J Med 1990; 322(2): 95-9.

http://dx.doi.org/10.1056/NEJM199001113220205 PMID: 2248624

[166] Erol A, Karpyak VM. Sex and gender-related differences in alcohol use and its consequences: Contemporary knowledge and future research considerations. Drug Alcohol Depend 2015; 156: $1-13$.

http://dx.doi.org/10.1016/j.drugalcdep.2015.08.023 PMID: 26371405

[167] McHugh RK, Votaw VR, Sugarman DE, Greenfield SF. Sex and gender differences in substance use disorders. Clin Psychol Rev 2018; 66: 12-23.

http://dx.doi.org/10.1016/j.cpr.2017.10.012 PMID: 29174306

[168] Chrostek L, Jelski W, Szmitkowski M, Puchalski Z. Gender-related differences in hepatic activity of alcohol dehydrogenase isoenzymes and aldehyde dehydrogenase in humans. J Clin Lab Anal 2003; 17(3): 93-6. http://dx.doi.org/10.1002/jcla.10076 PMID: 12696080

[169] Qiao Q, Hong Y, Zhao W, et al. Sex differences in outcomes and associated factors among stroke patients with small artery occlusion in China. Biol Sex Differ 2018; 9(1): 35 http://dx.doi.org/10.1186/s13293-018-0194-6 PMID: 30071887

[170] Corella D, Tucker K, Lahoz C, et al. Alcohol drinking determines the effect of the APOE locus on LDL-cholesterol concentrations in men: the Framingham Offspring Study. Am J Clin Nutr 2001; 73(4): 736-45. http://dx.doi.org/10.1093/ajcn/73.4.736 PMID: 11273848

[171] Palmisano BT, Zhu L, Stafford JM. Role of estrogens in the regulation of liver lipid metabolism. Adv Exp Med Biol 2017; 1043: 227-56.

http://dx.doi.org/10.1007/978-3-319-70178-3_12 PMID: 29224098

[172] Knopp RH, Paramsothy P, Retzlaff BM, et al. Sex differences in lipoprotein metabolism and dietary response: basis in hormonal differences and implications for cardiovascular disease. Curr Cardiol Rep 2006; 8(6): 452-9.

http://dx.doi.org/10.1007/s11886-006-0104-0 PMID: 17059798

[173] Cutini PH, Campelo AE, Agriello E, Sandoval MJ, Rauschemberger MB, Massheimer VL. The role of sex steroids on cellular events involved in vascular disease. J Steroid Biochem Mol Biol 2012; 132(3-5): 322-30.

http://dx.doi.org/10.1016/j.jsbmb.2012.08.001 PMID: 22903158

[174] Thor D, Zhang R, Anderson L, Bose DD, Dubé GP, Rahimian R. Effects of $17 \beta$-estradiol on lipopolysacharride-induced intracellular adhesion molecule- 1 mRNA expression and $\mathrm{Ca}^{2}+$ homeostasis alteration in human endothelial cells. Vascul Pharmacol 2010; 53(5-6): 230-8.

http://dx.doi.org/10.1016/j.vph.2010.09.001 PMID: 20843480

[175] Leite MLC, Moriguchi EH, Lima-Costa MF. Interactive effects of ApoE polymorphism, alcohol and smoking on age-related trends of blood pressure levels in elderly men: the Bambuì Cohort Study of Ageing (1997-2008). J Hum Hypertens 2013; 27(8): 497-503. http://dx.doi.org/10.1038/jhh.2012.70 PMID: 23324992

[176] Koch M, Fitzpatrick AL, Rapp SR, et al. Alcohol Consumption and Risk of Dementia and Cognitive Decline Among Older Adults With or Without Mild Cognitive Impairment. JAMA Netw Open 2019; 2(9): e1910319.

http://dx.doi.org/10.1001/jamanetworkopen.2019.10319 PMID: 31560382

[177] Slayday RE, Gustavson DE, Elman JA, Beck A, McEvoy LK, Tu $\mathrm{XM}$, et al. Interaction between Alcohol Consumption and Apolipoprotein E (ApoE) Genotype with Cognition in Middle-Aged Men. J Int Neuropsychol Soc 2020; $\cdots:$ : 1-13. http://dx.doi.org/10.1017/S1355617720000570 PMID: 32662384

[178] Mukamal KJ, Chung H, Jenny NS, et al. Alcohol use and risk of ischemic stroke among older adults: the cardiovascular health study. Stroke 2005; 36(9): 1830-4.

http://dx.doi.org/10.1161/01.STR.0000177587.76846.89 PMID: 16081863

[179] Mukamal KJ, Chung H, Jenny NS, et al. Alcohol consumption and risk of coronary heart disease in older adults: the Cardiovascular Health Study. J Am Geriatr Soc 2006; 54(1): 30-7.

http://dx.doi.org/10.1111/j.1532-5415.2005.00561.x PMID: 16420195

[180] Gordis E. National Institute on Alcohol Abuse and Alcoholism. Br J Addict 1988; 83: 483-93.

http://dx.doi.org/10.1111/j.1360-0443.1988.tb02567.x PMID: 2838115

[181] Collins R, Reith C, Emberson J, et al. Interpretation of the evidence for the efficacy and safety of statin therapy. Lancet 2016; 388(10059): 2532-61.

http://dx.doi.org/10.1016/S0140-6736(16)31357-5 PMID: 27616593

[182] LaRosa JC, Grundy SM, Kastelein JJP, Kostis JB, Greten H. Safety and efficacy of Atorvastatin-induced very low-density lipoprotein cholesterol levels in Patients with coronary heart disease (a post hoc analysis of the treating to new targets [TNT] study). Am J Cardiol 2007; 100(5): 747-52. [TNT].

http://dx.doi.org/10.1016/j.amjcard.2007.03.102 PMID: 17719314

[183] Thompson JF, Hyde CL, Wood LS, et al. Comprehensive whole- 
genome and candidate gene analysis for response to statin therapy in the Treating to New Targets (TNT) cohort. Circ Cardiovasc Genet 2009; 2(2): 173-81.

http://dx.doi.org/10.1161/CIRCGENETICS.108.818062 PMID: 20031582

[184] Zhang L, He S, Li Z, et al. Apolipoprotein E polymorphisms contribute to statin response in Chinese ASCVD patients with dyslipidemia. Lipids Health Dis 2019; 18(1): 129

http://dx.doi.org/10.1186/s12944-019-1069-5 PMID: 31153375

[185] Chiodini BD, Franzosi MG, Barlera S, et al. Apolipoprotein E polymorphisms influence effect of pravastatin on survival after myocardial infarction in a Mediterranean population: the GISSI-Prevenzione study. Eur Heart J 2007; 28(16): 1977-83.

http://dx.doi.org/10.1093/eurheartj/ehm196 PMID: 17567623

[186] Jabr R, Gharaibeh M, Zayed AA, Zihlif M. The Association between Apolipoprotein E Polymorphism and Response to Statins in Group of Hyperlipidemic Patients. Endocr Metab Immune Disord Drug Targets 2020; 20

http://dx.doi.org/10.2174/1871530320666200705211656 PMID: 32628603

[187] Lv P, Zheng Y, Huang J, Ke J, Zhang H. Association of apolipoprotein e gene polymorphism with ischemic stroke in coronary heart disease patients treated with medium-intensity statins. Neuropsychiatr Dis Treat 2020; 16: 2459-66.

http://dx.doi.org/10.2147/NDT.S265194 PMID: 33122909

[188] Christidis DS, Liberopoulos EN, Kakafika AI, et al. The effect of apolipoprotein E polymorphism on the response to lipid-lowering treatment with atorvastatin or fenofibrate. J Cardiovasc Pharmacol Ther 2006; 11(3): 211-21.

http://dx.doi.org/10.1177/1074248406293732 PMID: 17056835

[189] Zhang H, Zhou W, Cao C, Zhang W, Liu G, Zhang J. Amelioration of atherosclerosis in apolipoprotein E-deficient mice by combined RNA interference of lipoprotein-associated phospholipase A2 and YKL-40. PLoS One 2018; 13(8): e0202797.

http://dx.doi.org/10.1371/journal.pone.0202797 PMID: 30138439

[190] Gough PJ, Raines EW. Gene therapy of apolipoprotein E-deficient mice using a novel macrophage-specific retroviral vector. Blood 2003; 101(2): 485-91.

http://dx.doi.org/10.1182/blood-2002-07-2131 PMID: 12393475

[191] Yuan T, Zhong Y, Wang Y, et al. Generation of hyperlipidemic rabbit models using multiple sgRNAs targeted CRISPR/Cas9 gene editing system. Lipids Health Dis 2019; 18(1): 69.

http://dx.doi.org/10.1186/s12944-019-1013-8 PMID: 30885208

[192] Wacker BK, Dronadula N, Zhang J, Dichek DA. Local vascular gene therapy with apolipoprotein A-I to promote regression of atherosclerosis. Arterioscler Thromb Vasc Biol 2017; 37(2): 316-27.

http://dx.doi.org/10.1161/ATVBAHA.116.308258

PMID: 27932352

[193] Zhao H, Li Y, He L, et al. In Vivo AAV-CRISPR/Cas9-Mediated Gene Editing Ameliorates Atherosclerosis in Familial Hypercholesterolemia. Circulation 2020; 141(1): 67-79. http://dx.doi.org/10.1161/CIRCULATIONAHA.119.042476 PMID: 31779484 